DOI: https://doi.org/10.34305/nnc.v111.112

\title{
ANALISIS FAKTOR PREDISPOSISI DENGAN KEJADIAN PERILAKU KEKERASAN PADA PASIEN GANGGUAN JIWA DI RSUD 45 KABUPATEN KUNINGAN TAHUN 2019
}

\author{
Vica Novalia, Cecep Heriana, Muhammad Didik
}

Sekolah Tinggi Ilmu Kesehatan Kuningan Garawangi

cecepheriana@gmail.com

\begin{abstract}
Abstrak
Gangguan jiwa menjadi masalah serius baik secara global maupun nasional, regional bahkan pada tingkat lokal. Gangguan jiwa di Kabupaten Kuningan terus meningkat setiap tahunnya, termasuk yang melakukan perawatan di Rumah Sakit, 40\% diantaranya pasien dengan perilaku kekerasan. Pasien yang dirawat dirumah sakit dengan diagnosa yang sama mempunyai faktor predisposisi yang berbeda beda, faktor predisposisi yang berbeda ini merupakan informasi yang penting untuk dijadikan dasar pedoman asuhan keperawatan pada pasien dengan gangguan jiwa. Penelitian ini bertujuan untuk Menganalisis Faktor Predisposisi dengan Kejadian Perilaku Kekerasan pada Pasien Gangguan Jiwa di RSUD 45 Kabupaten Kuningan Tahun 2019.

Jenis Penelitian analitik observasional dengan pendekatan cross sectional. Populasi penelitian seluruh pasien jiwa dari bulan januari - maret sebanyak 68 orang. Sampel penelitian ini adalah seluruh Pasien jiwa di RSUD 45 Kabupaten Kuningan yaitu sebanyak 68 responden dan diambil dengan Teknik total sampling Data dari pasien dan di konfirmasi ke keluarganya diperoleh melalui kuesioner, data penelitian dianalisis dengan menggunakan uji chi square.

Analisis Bivariat faktor biologis $\rho$ value $=0,002$, faktor psikologis $\rho$ value $=0,004$, faktor sosial budaya $\rho$ value $=0,003$. Kesimpulan : terdapat hubungan faktor biologis, faktor psikologis dan faktor sosial budaya terhadap perilaku kekerasan pasien gangguan jiwa di RSUD 45 Kabupaten Kuningan tahun 2019. Saran Bagi pasien serta keluarga diharapkan menjalankan setiap instruksi yang diberikan oleh perawat atau tim medis selama menjalani perawatan. Keluarga sebaiknya memberikan dukungan secara tepat selama perawatan di rumah sehingga mengurangi adanya kekambuhan pada waktu yang akan datang
\end{abstract}

Kata kunci: Faktor-Faktor Predisposisi Perilaku Kekerasan

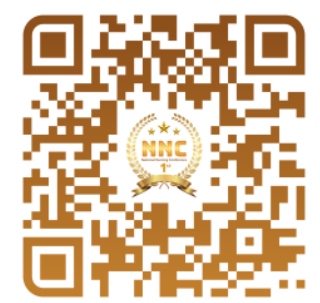

